\title{
For and about Etienne de Villiers as ethicist of responsibility
}

\author{
Authors: \\ Daniël P. Veldsman ${ }^{1}$ \\ Conrad J. Wethmar ${ }^{1}$ \\ Affiliations: \\ ${ }^{1}$ Department of Dogmatics \\ and Christian Ethics, \\ University of Pretoria, \\ South Africa \\ Correspondence to: \\ Danie Veldsman \\ Email: \\ danie.veldsman@up.ac.za \\ Postal address: \\ Private Bag X20, Hatfield, \\ Pretoria 0028, South Africa \\ How to cite this article: \\ Veldsman, D.P. \& Wethmar, \\ C.J., 2012, 'For and about \\ Etienne de Villiers as ethicist \\ of responsibility', Verbum \\ et Ecclesia 33(2), Art. \#805, \\ 2 pages. http://dx.doi. \\ org/10.4102/ve.v33i2.805
}

(C) 2012. The Authors. Licensee: AOSIS OpenJournals. This work is licensed under the Creative Commons Attribution License.
The retirement of Etienne de Villiers as professor of Christian Ethics, Faculty of Theology at the University of Pretoria (1994-2010) provides the opportunity to formally call to mind the remarkable contribution that he made to the theological scene in South Africa during a very special period in the history of this country.

When he came to Pretoria in 1994, De Villiers was faced with the daunting challenge as ethicist as he was the successor of the well-known professor Johan Heyns. He soon however proved himself to be equal to the task. He was well prepared for holding this position having had an excellent theological education which included BTh and MA (Philosophy) degrees from Stellenbosch University and a ThD degree in Christian Ethics from the Free University in Amsterdam, The Netherlands. In addition to this he had an early exposure to the world of scholarship having been appointed to a lecturing post at the Huguenot College in Wellington in 1979. All of this enabled him gradually to develop an own theological profile.

Three separate phases can be distinguished in his development as a theologian. Originally coming from a background of evangelical pietism, his exposure to the Enlightenment influences, which he encountered at Stellenbosch and Amsterdam, led to a first attempt to cope with the challenges by rationalist and empiricist critics of the Christian faith. The result of this confrontation can be seen in his doctoral dissertation of 1978 in which he defended the view that Christian morality has a distinctive content in opposition to his promoter, Professor H.M. Kuitert's idea of a natural clarity of moral notions.

During his Wellington period, confronted by the turbulent events in the South Africa of the seventies and eighties of the previous century, De Villiers in the second phase of his development mainly worked on issues related to justice and peace. Especially noticeable during these years was the view that he consistently defended various contexts, namely that Christians are called not to conquer a particular enemy, but enmity as such.

The third phase of De Villiers' theological development started with his move to Pretoria which happened to coincide with the South African political transformation of 1994. At this stage the focus of his work moved to the question what the task of the church and Christian ethics should be in the public sphere of a liberal democracy.

Although it seems possible to distinguish three separate phases in De Villiers' career, closer scrutiny reveals that all three phases, in fact, deal with the same basic problem, which is the quest for the distinctive character of Christian morality. What did, however, happen was that the answer that he gave to this question has gradually undergone a certain development. Whilst he initially answered the question by proposing a duty ethic in which the Christian distinctiveness consisted of both the motivation and contents of the relevant duty, he gradually came to agree with Hauerwas that the distinctiveness of a Christian ethic should rather be found in the attitudes and virtues that Christians develop.

During the third phase of his career De Villiers came to the further conclusion that, whilst virtues and attitudes are indispensable formational factors in Christian behaviour, they are not comprehensive enough. In particular situations not only are specifically Christian values operative, but in addition also the functional values pertaining to that specific situation. And the fundamental question for a Christian ethic is how the interaction of Christian and functional values can be dealt with in a manner that does justice to both. The position that De Villiers, therefore, currently defends is that the answer to this question can be found in a Christian version of an ethics of responsibility.

In order to celebrate this very remarkable theological-ethical contribution of Etienne de Villiers, the Department of Dogmatics and Christian Ethics, Faculty of Theology, University of Pretoria 
organised a Research Day on 09 November 2011. Nine papers were read on that day by former colleagues, invited international and national scholars and students of De Villiers. Unfortunately one of the valued contributions, namely that of Prof. Gerrit de Kruijf on 'Christelike Etiek en demokrasie' could not be included, due to his sudden unexpected ill health. However, six of the papers read on the Research Day are published in this special Festschrift edition as well as five contributions by scholars honouring the work of De Villiers. In the first five contributions, scholars engage directly with De Villiers in his work as 'Etikus van Verantwoordelikheid' by Dirkie Smit; on economic-ethical perspectives in 'Virtue and Responsibility' by Piet Naude; and personal-ethical perspectives by Andrè van Niekerk; on his work as well as his far-reaching contribution to public theology, 'Public Theologies in Pluralistic Societies' by Nico Koopman; and to ecclesial-ethical reflection on ecumenical contexts 'Ekklesiologie en Etiek' by Conrad Wethmar. In the following further six contributions, scholars address contemporary doctrinal-ethical issues such as an ethical responsible manner to respond to catastrophic risks, 'After
Fukushima' by Wolfgang Huber; the deep contradiction between malnourishment and starvation on the one hand and the biblical notion of the preferential option for the poor on the other hand 'Food Justice and Christian Ethics' by Heinrich Bedford-Ströhm; a critical re-evaluation of 'revealed theology', 'Escaping from the Ghetto' by Vincent Brümmer; witnessing to Christ in an African context, 'Reading of the African Context' by Musonda Bwalya; in the face of secularism 'Christian Ethics' by Jacobus Vorster; and the growing impact of modernism on the South African population and its various consequences, 'The Neglected Context' by Klaus Nürnberger. In the last contribution, the celebrant - Etienne De Villiers - reflects after 30 years on the distinctiveness of Christian morality.

Prof. Danie Veldsman

Guest Editor

Prof. Conrad Wethmar

Guest Editor 